Prof. Charmaine

du Plessis

Department of

Communication Science,

Unisa

(dplestc@unisa.ac.za)

DOI: https://dx.doi. org/10.18820/24150525/

Comm.v22.3

ISSN 2415-0525 (Online)

Communitas 201722: 31-47

(c) UFS

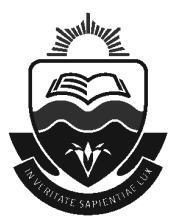

\section{MOBILE MARKETING: BUILDING BLOCKS FOR MOBILE CONTENT MARKETING TO ADD VALUE AND RELEVANCE FOR MOBILE USERS}

\begin{abstract}
Optimal communication with a target audience from a mobile platform remains elusive, particularly as a result of evolving phone technology and users' privacy concerns. Since it is standard practice now for consumers to access the internet via mobile phones, messages should not address a general audience but unobtrusively blend with the individual user's daily life. While many mobile marketers rely on the "push" technique through mobile messaging, various studies indicate that pushing messages is not always efficient and can alienate mobile users who prefer unique forms of brand-related engagement. The view informing this article is that barriers hampering mobile marketing such as perceived untrustworthiness, irrelevance and low value could be eliminated through mobile content marketing, and in particular through unobtrusive pulling techniques using patrons as proposed in Kaplan's (2012) classification. Based on the results of a directed qualitative content analysis of industry white papers on mobile marketing, this study is centred on a proposition that a content marketing approach should be promoted for mobile marketing communication.
\end{abstract}

Keywords: content analysis; content marketing; mobile marketing; mobile content marketing; mobile marketing communication; patrons; Kaplan; branding; brand messages

\section{INTRODUCTION}

\begin{abstract}
I think the biggest change, and the one we're already starting to see take shape, is that globally the majority of internet usage will be done via a mobile device and for most people the mobile web will be their primary - if not their only - way of experiencing the internet (Rojas, in Adler 2014).
\end{abstract}

This prediction by Peter Rojas, formerly associated with the technology blog Gizmodo and currently with Engadget, became a reality when Google announced in 2015 that more than half of all searches are now done on mobile devices. This development has huge implications for branding in that brand messages might soon be seen mainly by users on a company's mobile website or device (Sterling 2015). 
Regrettably mobile marketing has been hamstrung by the contrast between its intrusive nature and mobile users' essential need for privacy that enables them to manage their social lives with their smartphones. Issues around trust and reaching the right target audience therefore persist (cf. Kelley's (2014) observation that $80 \%$ of mobile marketing efforts are either unavailing, abandoned or irreconcilable with the brand's overall strategy).

Mobile marketing has nevertheless made some progress over the years in that companies realise how important it is to have a mobile marketing strategy. Today marketers use multimedia mobile platforms (mobile applications) and mobile internet browsers supplemented by social media applications and platforms, such as quick response $(Q R)$ codes, to reach the target audience in a more personalised manner (Santos 2015). Although marketers are "mobile-ready" and appreciate that mobile phones facilitate more personal communication, they are often not up to date with the persistent evolution of mobile technologies (Shankar et al. 2010). Mobile applications are also expensive for brands to build, maintain and track (Bergen 2014).

Attempts to understand mobile marketing (m-marketing) have produced studies in a wide range of areas. These include consumer acceptance and experiences (Bauer et al. 2005), consumption (Chan-Olmsted et al. 2013), privacy (Almuhimedi et al. 2015), adoption (Sanakulov \& Karjaluoto 2015), value (Andrews et al. 2012; Wang 2015), campaigns and advertising (Bart et al. 2014), a variety of mobile applications (Harrison et al. 2013), mobile commerce (Sharif et al. 2014) and theory building (Pousttchi \& Wiedemann 2006).

Marketers should not only understand evolving mobile technologies, but also be aware of the unique nature of a mobile platform and know how to become part of consumers' daily lives. As consumers increasingly access the internet via their mobile phones to complement their lifestyles, the research of Ghose et al. (2013) indicates that consumer behaviour is different on a mobile platform; therefore, the same mobile message will not be equally arresting to all users.

Mobile marketing from a mobile commerce (m-commerce) perspective is defined as "any kind of business transaction, on the condition that at least one side uses mobile communication techniques" (Pousttchi \& Wiedemann 2006). However, this narrow perception that it is mostly advertising on a mobile distribution platform has widened its essential communication role as consumers expressed a need for more value. This realisation presents a unique opportunity for marketers to promote personalised communication. Since smartphones have more capabilities that can accommodate so-called pull as well as pushing techniques, this article proposes some building blocks to engage mobile users who have already expressed an interest in a brand. A mobile phone is perhaps not the ultimate platform to reach new customers, but rather a personalised way of retaining and engaging interested parties. Accordingly this article seeks to investigate an underexplored area of research and fill a gap in academic literature by understanding how issues around trust, relevance and value could be addressed by mobile content marketing, with particular reference to pulling techniques as classified by Kaplan (2012). 
The article is structured as follows. Firstly, mobile marketing is positioned within the marketing communication and content marketing fields to clarify its scholarly foundation. Thereafter, it is explained how mobile content marketing could benefit mobile marketing communication when pulling patrons, followed by a discussion of the research question and research methodology. Lastly, based on the findings, three building blocks for mobile marketing as content marketing are proposed with some concluding remarks.

\section{POSITIONING MOBILE COMMUNICATION}

Given the many perspectives on mobile marketing in the media today, it is important to clarify its scholarly foundation in support of the building blocks which are proposed towards the end of this article.

Mobile marketing is no longer viewed as mere m-commerce, but as an important part of marketing communication, which subsumes a wide range of communication possibilities, such as collecting customer relationship management (CRM) data, streaming media, messages and providing downloadable content. All forms of media can now be integrated by this means to enable electronic mobile-word-of-mouth (eWOM), a type of mobile viral marketing (Castronovo \& Huang 2012). Palka et al. (2009) define mobile viral marketing as "a concept for distribution or communication ... a type of marketing [which] relies on consumers to transmit mobile viral content via mobile communication techniques and mobile devices to other consumers in their social sphere and to animate these contacts to also transmit the content".

Pousttchi and Wiedemann's (2006) view that mobile marketing is part of the fourth P of the marketing mix, namely promotion (otherwise known as marketing communication), is still widely influential and focuses on using various communication instruments to communicate with consumers. Former criticism of its lack of personalisation is laid to rest by recognising mobile marketing as a communication instrument of the marketing communication mix (Constantinides 2006).

Kaplan's (2012: 130-131) highly cited classification of mobile marketing is relevant to marketing communication in that it clearly identifies the trigger for communication with mobile users based on what is known about them. He classifies this trigger according to strangers, cohort groupies, victims and patrons. A company that is relatively ignorant about mobile users reaches them by means of push technologies with a general message sent to the masses (referred to as strangers). Another trigger for communication is to pull mobile users in order to get them to opt-in to receive information about the brand (referred to as cohort groupies since not much information is known about them). However, personalised communication remains a challenge with this group. The third group refers to communication with mobile users who are known to the company and are receiving pushed information without first asking permission (referred to as victims). The fourth group includes mobile users who have given permission to be contacted and who provided personal information for more custom-made communication with them (referred to as patrons). Patrons are thus 
the right mobile users to communicate with in a more personalised manner and to be enticed to pull more information about the brand.

Pulling techniques are especially extendable to patrons (cf. Beard 2014). As a mobile phone assists consumers to find relevant information it could play a valuable role in not only enhancing brand awareness and understanding but also holding users' attention via engagement. Content marketing is ideal to address mobile messages to patrons as it uses unobtrusive pulling and not merely pushing techniques to attract consumers to brand content (cf. Liu \& Huang 2014).

Numerous perspectives about content marketing still proceed from practitioners' epistemologies and perspectives (cf. Myllys 2016; Du Plessis 2015; Symons 2015; Holliman \& Rowley 2014). There is nevertheless consensus that content marketing involves pulling techniques to attract readers to brand stories about content they are already searching for (Du Plessis 2015). Pulizzi's (2012) point of view that storytelling is the key to successful content marketing is still widely acknowledged. He states that the company consistently creates and pulls "valuable, relevant and compelling content" to entice some positive behaviour from a customer or prospect. In this regard Schimke $(2015 ; 2016)$ argues that since a mobile phone is a personal item, mobile marketing communication within a content marketing approach has much potential to become trusted or perceived as having relevance and value.

Although content marketing as a marketing paradigm is academically argued, there is no scholarly literature on what mobile content marketing is. The issue of optimising mobile experience for content marketing by practitioners and professional bodies such as the Content Marketing Institute (CMI) is, however, a topic of much interest. For lack of a formally accepted definition, mobile content marketing is conveniently defined as "a mesh between content marketing (creating useful content to attract customers) and mobile marketing (marketing to mobile device users)". Content is thus optimised for mobile to attract and engage existing and potential customers (West n.d.; Bedor 2016).

\section{PUSH VS PULL MOBILE COMMUNICATION}

There is still no final answer as to whether marketers should rather use push or pull mobile communication, simply because there are so many options to consider in this regard. Unni and Harmon (2007) explain that push, in the context of traditional marketing, refers to the use of trade promotions to ensure that stocks will last, while pull uses mass advertising and consumer promotions to create demand for a brand. However, within the context of location-based advertising and other forms of nontraditional marketing, push refers to outbound communication originating from the marketer as a direct-response marketing message or advertisement, whereas pull is inbound communication that is initiated by the consumer, based on interest. For mobile communication it could include push notifications through mobile applications, application of fresh features, or promotion alerts.

On the other hand, mobile users are pulled to relevant information and resources, for example by retrieving coupons after texting a keyword (Moulin 2014). As noted, numerous perspectives exist as to whether to use push or pull communication via 
mobile platforms. For example, arguments draw attention to each offer's different benefits depending on entry barriers, target consumer, industry and the available budget. An earlier study by Okazaki (2004) found that users are more receptive to pulled mobile communication because it is informative and entertaining, while pushing messages could be perceived as annoying. Similarly a mobile study by Lai et al. (2012) points towards users favouring pulling techniques to become involved in mobile shopping. Since push mobile communication is still deemed evasive, unsolicited and even inclined to malicious advertising in some instances of free mobile applications, pulling mobile communication to patrons could be an acceptable alternative. Kaplan and Haenlein (2011) refer to a unique combination of push and pull communication "from the sender to followers, from followers to followers and from receivers to external information sources" in a microblogging environment. This view could also be extended to a mobile environment in that information that is pushed to mobile users may be read but not really have relevance and thus be easily forgotten. However, when messages are considered relevant they are pulled by the mobile user for additional information.

Hagel et al. (2010) identify three levels of pulling within an organisational performance context, namely access, attract and achieve. If their views are considered within a mobile context, with particular reference to mobile content marketing, users could be constantly connected to a "flow of knowledge" by accessing a relevant mobile community and resources to which they are attracted based on their interest and the opportunity to participate. Attracting the right kind of users to this "flow of knowledge" could result in the right kind of interactions, which could lead to more knowledge about the brand that could prove useful in the present contexts as well as in future strategies.

In addition, Vee et al.'s concept (2008) of gravitational marketing could also be applied to pulling mobile communication at the point of letting users opt in to receive communication to be able to connect with them as patrons. Said authors propose that a list based on direct-response and relationship marketing be drawn of people who are interested in the brand and that attention be focused exclusively on them. Once the brand is familiar with what the customer wants, a message is created that attracts the customer, namely the problem being solved, fulfilling hopes, and the reason why people should care about its products/and or services. Attraction is based on consumers' interest (being enjoyable, funny and conversational) and uniqueness (standing out) and thus shareable content (problem-solving). Mobile users could be attracted to empowering content that stands out because of its relevance to their own lives which they would want to pass on to other interested users.

Pousttchi and Wiedemann's (2006) study identified four types of values that could be pulled to consumers via mobile phones which link up with gravitational marketing. These values include the information, entertainment, raffle-and-coupon, and standard types. The information standard type refers to the perceived value of the information, for example about products, nearest point of sale, mobile newsletters and other relevant information. The entertainment standard type refers to entertainment that has amusement and emotional value for the consumer, such as video, music, games and mobile customisation offerings to encourage different contact points. The raffle standard type refers to mobile bidding where mobile users answer a question, 
vote for something or someone, or send a certain code by SMS for a chance to win cash and goods prizes which are either digital or non-digital. The main advantage of raffles is that the prize provides customers with a tangible reason to contact the advertisers. The more attractive the prize is to the target group, the higher the chance of success, because customers compare the probability of winning with the estimated value of the prize and then decide to participate in the campaign. The coupon standard type refers to a monetary incentive sent to the user's mobile device which could be redeemed at the point of sale, for example, discounts and trial packages. In this study a sense of belonging is added as another standard type that can be achieved with brand storytelling, a technique involving stories about the brand that is gaining increasing traction and could be extended to a mobile platform to develop brand loyalty. Brands could share brand updates via stories that are mobile friendly and could be accessed at various entry points, for example, by using video, images and text to make users feel part of the mobile brand community (Du Plessis 2015).

\section{RESEARCH QUESTION}

The aim of this study was to answer the following research question: How could mobile marketing communication benefit from content marketing to add value and relevance to consumers' daily lives?

\section{RESEARCH METHODOLOGY}

For this study a directed content analysis of industry white papers concerning best mobile marketing practices was conducted. Content analysis is a widely adopted method because of its ability to make replicable and valid inferences of analysed text data. Content analysis was a functional method for this study since research about content marketing within the context of mobile marketing is lacking and would benefit from further description (Hsieh \& Shannon 2005: 1277).

A total of 71 full-text copies of white papers serving as best practice illustrations for mobile marketing were accessed online through search engine searches. Hoffman (2017) explains that a white paper provides insight into a topic by advocating for a specific solution to a problem and thus functions as thought leadership. These documents were purposively selected as they represent topical contributions concerning the use of content in mobile marketing. They are also longer (on average 20 pages), convey practical information, and are more substantial than blog posts. Since this study is exploratory, 71 documents were deemed enough to provide a snapshot idea of current mobile marketing practices when it comes to creating and sharing content. The units of analysis were social artefacts (white paper documents).

The data analysis was as follows. At first Miles and Huberman's (1994) approach was followed to reduce the data in an accurate manner. Thereafter, key concepts or variables were identified in accordance with the literature followed by formulating operational definitions for all pre-determined categories. All documents were examined on both manifest (what the text is saying) and latent levels (the deeper meaning in the text) (Bengtsson 2016: 9). After this systematic review the text was coded into 
categories and highlighted where the data represented instances of a pre-determined category. In the last step, subcategories were identified where needed (Hsieh \& Shannon 2005: 1282). The final code frame consisted of 23 individual codes located across three main categories.

The issue of coding reliability was addressed by following up the initial manual coding with coding via a qualitative data analysis software programme, QDA Miner, by Provalis Research. This ensured that data was thoroughly interrogated and follows coding reliability suggestions by Welsch (2002). It is widely argued in academic literature that a computer-programme-assisted analysis ensures higher reliability than human coding techniques (Silver \& Lewins 2007).

\section{FINDINGS}

Three categories with two subcategories respectively emerged from the data. Table 1 illustrates the three main categories, number of cases, codes and frequency, which are discussed in more detail below. It can be inferred from this table that content marketing could play a role in mobile marketing to attract and retain patrons. Each category is explained in more detail below with the proposed building blocks to follow in the subsequent section.

TABLE 1: THREE MAIN CATEGORIES AND FREQUENCY IN DATA

\begin{tabular}{|c|c|c|c|c|c|}
\hline Category & Description & Frequency & $\%$ Codes & Cases & $\%$ Cases \\
\hline $\begin{array}{l}\text { Purpose } \\
\text { of mobile } \\
\text { content } \\
\text { marketing }\end{array}$ & $\begin{array}{l}\text { Purpose of mobile } \\
\text { marketing when it } \\
\text { comes to sharing } \\
\text { and creating } \\
\text { content for a } \\
\text { mobile platform }\end{array}$ & 411 & $36.40 \%$ & 53 & $74.60 \%$ \\
\hline $\begin{array}{l}\text { Level of } \\
\text { content } \\
\text { pulling }\end{array}$ & $\begin{array}{l}\text { How users } \\
\text { already interested } \\
\text { in the brand } \\
\text { are attracted to } \\
\text { mobile content } \\
\text { and then retained }\end{array}$ & 231 & $20.50 \%$ & 51 & $71.80 \%$ \\
\hline $\begin{array}{l}\text { Engaged } \\
\text { mobile } \\
\text { community }\end{array}$ & $\begin{array}{l}\text { Content } \\
\text { marketing actions } \\
\text { to retain patrons' } \\
\text { interest after they } \\
\text { have opted-in to } \\
\text { become part of a } \\
\text { mobile community }\end{array}$ & 486 & $43.10 \%$ & 58 & $81.70 \%$ \\
\hline
\end{tabular}




\section{Category 1: Purpose of mobile content marketing}

Category 1 encompasses all findings relating to the purpose of mobile marketing when it comes to sharing and creating content for a mobile platform. It constitutes $36.40 \%$ of the codes. It is important to be goal-oriented when devising content for mobile platforms to entice patrons already interested in the brand with relevant and timely content at "key moments". Two subcategories also became evident, namely that of mobile interaction and mobile experience. This category firstly illustrates that the purpose of the content should foremost centre around interactivity, building relationships, engagement and being personalised. Mobile interaction is "an integral part of owning a mobile phone" and it is, therefore, important that the brand should be "part of the conversations that matter to local and online communities". In addition, marketing via mobile devices is about "unlocking the potential of a huge, expanding, captive and engaged audience". Equally important is that "mobile engagement can deepen relationships between a brand and customers by delivering the right message at the right moment across channels and devices". It is thus important to provide "customers with content that is timely and relevant".

Secondly, the purpose should be to enable a "seamless", carefully managed mobile experience "across devices and platforms to create a more rewarding cross-channel experience". This could also be achieved by "enabling integration with both the Web and social media". The customer experience with the content should thus be the same irrespective of where the entry point is. This mobile-optimised experience should preferably be part of a larger framework such as the overall marketing strategy to enhance the "total brand experience". The mobile experience could also be enhanced through "augmented reality" technology to bring the brand closer to the mobile user.

TABLE 2: CATEGORY 1: PURPOSE OF MOBILE CONTENT MARKETING

\begin{tabular}{|l|l|l|}
\hline \multicolumn{3}{|c|}{ Category 1: Purpose of mobile content marketing } \\
\hline Subcategories & Mobile interaction & Mobile experience \\
\hline Codes & Interactivity & Cross-channel \\
\hline & Building relationships & Part of larger framework \\
\hline & Engagement & Management \\
\hline & Personalised content & Mobile-optimised \\
\hline & Relevance & Augmented reality \\
\hline
\end{tabular}

\section{Category 2: Level of content pulling}

Category 2 encompasses all findings relating to how users already interested in the brand are attracted to mobile content and then retained. It constitutes $20.50 \%$ of the codes. 
Two subcategories also became evident, namely that of unified customer data and participation. This category firstly illustrates that "data analytics around customer data provide customer insights" and assists with "focusing on quality messaging over quantity". Data analytics could also be integrated with location-based technology to "generate more insights into customer/user behavior". Since the users are already interested in the brand the mobile opt-in process could be facilitated with branded content and mobile promotions. It is thus important for marketers to "seek to leverage data to better understand customers including their businesses, the products and services they use, and the processes they prefer and then integrate that knowledge into campaigns". By understanding customer behaviour the opt-in process could include sending users "relevant location-based offers", but to enhance more trust "an automatically fixed period opt-out is perhaps a way of encouraging additional trust among audiences".

Secondly, it is also important to retain patrons through participation on a "rich user interface" which could, amongst others, include collaboration and peer to peer interactions. The interface should encourage users to engage with the content with ample interactive features. Equally important is that the brand also needs to be part of these interactions. User preferences should be accommodated by providing "helpful information, offers or entertainment based on geographic location". It is important to continuously "surprise and delight consumers" to retain them.

TABLE 3: CATEGORY 2: LEVEL OF CONTENT PULLING

\begin{tabular}{|l|l|l|}
\hline \multicolumn{3}{|c|}{ Category 2: Level of content pulling } \\
\hline Subcategories & Unified customer data & Participation \\
\hline Codes & Opt-in process & User preferences \\
\hline & Branded content & Collaboration \\
\hline & Mobile promotions & User-friendly interface \\
\hline & & Peer to peer \\
\hline
\end{tabular}

\section{Category 3: Engaged mobile community}

Category 3 encompasses all findings relating to content marketing actions to retain patrons' interest after they have opted-in to become part of a mobile community. It constitutes $43.10 \%$ of the codes.

Two subcategories also became evident, namely that of relevance and value. This category firstly illustrates that relevance of content and technology is also very important after the opt-in and not only before the opt-in process. Actions to engage patrons should be focused on a real-time context, integrated technology and consistent content delivery. Marketers could focus actions from insights on data retrieved from "real-time location data tracking" and provide content that is relevant to users at 
the right time. By consistently providing "relevant, technology infused content", the "unique differentiator" is personalised and real-time communication and experiences.

Secondly, patrons' perceived value to remain part of the mobile community is centred on individual needs, the opportunity to share knowledge and have access to exclusive content. By "optimising customer experience", through continuous interactions, patrons' individual needs could be addressed and ultimately enhance loyalty to the community. The brand should thus "fulfil the role of trusted partner" in real time. Patrons should additionally be given the opportunity to "provide knowledge, ideas, inspiration and skills on topics that members want to hear about". This gives members of the community access to unique, exclusive and valuable content which is applicable to their daily lives.

\section{TABLE 4: CATEGORY 3: ENGAGED MOBILE COMMUNITY}

\begin{tabular}{|l|l|l|}
\hline \multicolumn{3}{|c|}{ Category 3: Engaged mobile community } \\
\hline Subcategories & Relevance & Value \\
\hline Codes & Real-time context & Individualised needs \\
\hline & Integrated technology & Sharing knowledge \\
\hline & Delivery consistency & Content access \\
\hline
\end{tabular}

\section{DISCUSSION}

The discussion of the findings is anchored in three building blocks to connect with patrons via mobile content marketing and answers the research question how mobile marketing communication could benefit from content marketing to add value and relevance to consumers' daily lives.

The functional building blocks were derived by drawing on pertinent scholarly literature and practitioners' views that became evident from the three categories of the data of the content analysis. However, these building blocks should also be considered collectively as they are mutually supportive.

\section{Purpose of mobile content marketing}

This building block represents the unique purpose of engaging with patrons via a mobile platform that is part of the company's content marketing strategy, which although uniquely distinct, should include its objectives, target audience, channels, frequency and metrics (Baltes 2015). However, mobile content marketing should not be adopted only because it is essential nowadays, but because the company has a distinct long-term goal in mind. The goal could be to attract and retain users who are already interested in the brand and could presumably become repeat buyers. Marketers could build relationships with patrons by first attracting and then engaging them through relevant and unique mobile content marketing messages that captivate users' interest. In this way the brand builds a mutually beneficial mobile community 
through continued strategic, relevant mobile content marketing that allows users to participate (cf. Shankar \& Balasubramanian 2009).

Marketers using this building block should realise that mobile use will not produce an immediate return on investment (ROI), but that consistent use could benefit the brand in the long run.

\section{Level of mobile content marketing pulling for opt-in through attraction}

This building block represents the three levels on which information about users is collected and permission obtained to become part of a mobile community where they receive mobile content marketing messages as patrons on the three levels of attraction, access and achievement (Hagel et al. 2010). This building block furthermore refines the course of action to obtain and retain the patron's interest in the mobile content marketing messages. The opt-in (often referred to in content marketing as the lead magnet) acts as an enabler, enhancer or extra, which will be of value to the consumer in exchange for a mobile phone number, e-mail address and personal information (Hlavac 2014). This lead magnet is typically shared via both social and mobile platforms to attract patrons to access privileged information that they will find valuable as a means to achieve personal objectives in their daily lives. For example, a communication trigger could be presented via the brand's sign-up process on its mobile website, application(s) or mobile landing pages with clickable links, social media posts (directing users to owned media), or paid social media advertising to enable direct communication. Owned media comprise content over which a company has complete control (Corcoran 2010). Where mobile is concerned, consumers typically opt in by texting, scanning or submitting information to a mobile website or application (Russell 2016). Since mobile marketing is permission-based in many countries, a company's website often serves as a means of asking consumers for permission to communicate with them via their mobile phones (Scharl et al. 2005). Furthermore, at the point of opting-in, patrons are alerted to the opportunity to contribute meaningfully to the mobile community through their active participation. Lin (2013) refers to "socialised media" in which a community is formed based on its interactivity and two-way network platform capabilities. Users are attracted to this community because it allows their active participation. A study by Ind et al. (2013) confirms that people participate in a community when given the opportunity to do so meaningfully. Attracting patrons to a mobile community could produce the right kind of interactions and be beneficial to the brand as well (Hagel et al. 2010). Enough information could be obtained in this way to allow for more personalised communication.

The success of this building block depends on patrons' desire to have access to information, knowledge and resources and an opportunity to contribute meaningfully, which would not be available to them otherwise, unless they willingly subscribe and provide some personal information. 


\section{Identify the mobile content marketing focus for optimum relevance and value}

This building block represents the focused mobile content marketing actions to retain patrons' interest in the mobile community by adding value to their daily lives through relevant information. Rubin (2015) correctly notes that building a mobile community depends on the same principles of engaging, interacting, adding value and support that are used to build other communities.

Once the brand captures consumers' interest to receive mobile content marketing messages based on their interest, marketers have to provide relevant, continuous and attention-grabbing information to keep them engaged as part of a mobile community. If mobile users are not interested in the communication, they will unsubscribe from any further messages to the community. Bedor (2016) recommends the use of a "content-centric" mobile application that will allow frequent usage and personalisation of message. In this way a community could be built around the content. As suggested by Pousttchi and Wiedemann (2006), as well as Du Plessis (2015), mobile content marketing could focus on providing value to consumers, for example by solving their problems with value-based and rich information, creating and sharing stories to illustrate the brand in ways that add value to their daily lives, or by providing entertainment value that appeals.

The mobile platform and content marketing messages that will be best suited to retain patrons' interest are identified and consistently used to promote the success of using this building block; moreover, participation is encouraged and rewarded to serve the same end. Bullas (2014) argues that brand fans or advocates too should become eager to produce content (including visuals) to share with the mobile community. The information provided during the mobile opt-in process enables marketers to personalise their mobile content marketing to build a closer relationship with the consumer. The marketer unfailingly provides exclusive access to value for the benefit of patrons with a view to retain them in the community. Mass messages are no longer sent to mobile users who might not be interested, but instead seamless value is provided to an interested target audience within a mobile community that has the potential to become repeat customers (Vee et al. 2008).

Thus, in accordance with the concept of gravitational marketing advocated by Vee et al. (2008), this building block constitutes the "glue" to retain patrons' interest. The attraction of having access to the mobile content marketing messages and thereby making a contribution could be enhanced by being enjoyable, funny, conversational, and prominently visible through exclusivity and the ability to solve patrons' problems in daily life. Value would be enhanced at the same time by the continuous provision of useful information, entertainment, monetary incentives, or an opportunity to win a prize, or gain an enhanced sense of belonging (Du Plessis 2015; Pousttchi \& Wiedemann 2006).

The success of this building block would be dependent on nourishing patrons' interest in the brand by providing valuable, compelling and relevant brand content to which they could add significant meaning of their own. 


\section{CONCLUSION}

While exploratory in nature, this study offers several useful insights into how content marketing could play an important role in engaging with the target audience in a mobile marketing community. The findings have expanded understanding of how brands could use content marketing in mobile marketing communication by proposing three building blocks based on the findings of a directed content analysis. In doing so, the study provides sufficient evidence of how content marketing could benefit a brand by pulling rather than pushing messages to mobile users. Because of the study's limitations in terms of a small sample, it is proposed that future studies include a larger sample and also focus on marketers' perspectives to expand on this knowledge.

Mobile marketing has been plagued by numerous obstacles which have impeded its success. Companies that are serious about targeting the right mobile users will find the building blocks useful as a means of attracting users who are already interested in the brand, and of co-opting them into becoming part of a committed mobile brand community. Due consideration of the three building blocks could enable mobile marketers to reach the right mobile users more efficiently through alternative means. The brand could at the same time benefit from rich and relevant interactions through its exposure to a constant flow of knowledge in a mobile community. Using content marketing principles could facilitate the creation of the most appealing lead magnet on suitable platforms that will persuade mobile users to become part of a mobile community because of their interest in the brand. These mobile users could then be pulled constantly via content marketing to engage with relevant and valuable brand content to complement their lifestyle.

Pushed messages are still preferred by many mobile marketers, and they can certainly play a role when it comes to mobile applications. However, pushing messages to mobile users are also increasingly seen as intrusive and not providing any value, which could ultimately alienate mobile users.

\section{REFERENCES}

Adler, B. 2014. The 10 most telling quotes about the future of mobile. [Online]. Available at: http://info.localytics.com/blog/the-10-most-telling-quotes-about-the-future-ofmobile. [Accessed on 4 April 2017].

Almuhimedi, H., Schaub, F., Sadeh, N., Adjerid, I., Acquisti, A., Gluck, J. \& Agarwal, Y. 2015. Your location has been shared 5, 398 times! Proceedings of the 33rd Annual ACM Conference on Human Factors in Computing Systems 787-796. New York, United States of America.

Andrews, L., Drennan, J. \& Russell-Bennett. R. 2012. Linking perceived value of mobile marketing with the experiential consumption of mobile phones. European Journal of Marketing 46(3/4): 357-386. https://doi.org/10.1108/03090561211202512

Baltes, L.P. 2015. Content marketing - the fundamental tool of digital marketing. Bulletin of the Transilvania University of Braşov 8(57)(2): 111-118. 
Bart, Y., Stephen, A.T. \& Sarvary, M. 2014. Which products are best suited to mobile advertising? A field study of mobile display advertising effects on consumer attitudes and intentions. Journal of Marketing Research 51(3): 270-285. https://doi. org/10.1509/jmr.13.0503

Bauer, H., Reichardt, T., Barnes, S. \& Neumann, M. 2005. Driving consumer acceptance of mobile marketing: A theoretical framework and empirical study. Journal of Electronic Commerce Research 6(3): 181-191.

Beard, N. 2014. Mobile content marketing - what you need to know: Pros, cons, examples, best practices. [Online]. Available at: http://www.toprankblog.com/2014/01/mobilecontent-marketing/ [Accessed on 3 March 2017].

Bedor, L. 2016. The future of content marketing is mobile. [Online]. Available at: https:// marketinginsidergroup.com/content-marketing/future-content-marketing-is-mobile/ [Accessed on 3 March 2017].

Bengtsson, M. 2016. How to plan and perform a qualitative study using content analysis. NursingPlus Open 2: 8-14. https://doi.org/10.1016/j.npls.2016.01.001

Bergen, M. 2014. Why marketers just can't crack mobile. [Online]. Available at: http:// adage.com/article/news/marketers-crack-mobile/293249/ [Accessed on 4 April 2017].

Bullas, J. 2014. 10 ways to succeed with mobile content marketing. [Online]. Available at: http://www.jeffbullas.com/2014/12/19/10-ways-to-succeed-in-the-new-age-ofmobile-content-marketing/ [Accessed on 3 March 2017].

Castronovo, C. \& Huang, L. 2012. Social media in an alternative marketing communication model. Journal of Marketing Development and Competitiveness 6(1): 117-134.

Chan-Olmsted, S., Rim, H. \& Zerba, A. 2013. Mobile news adoption among young adults: Examining the roles of perceptions, news consumption, and media usage. Journalism \& Mass Communication Quarterly 90(1): 126-147. https://doi. org/10.1177/1077699012468742

Constantinides, E. 2006. The marketing mix revisited: Towards the 21st century marketing. Journal of Marketing Management 22(3-4): 407-438. https://doi. org/10.1362/026725706776861190

Corcoran, S. 2010. Sean Corcoran's Blog. [Online]. Available at: http://blogs.forrester. com/interactive_marketing/2009/12/defining-earned-owned-and-paid-media.html. [Accessed on 6 March 2017].

Du Plessis, C. 2015. An exploratory analysis of essential elements of content marketing. Proceedings of the Second European Conference on Social Media, 122-129. Porto, Portugal.

Ghose, A., Goldfarb, A. \& Han, S.P. 2013. How is the mobile Internet different? Search costs and local activities. Information Systems Research 24(3): 613-631. https://doi. org/10.1287/isre.1120.0453

Hagel, J., Brown, J.S. \& Davison, L. 2010. The power of pull: How small moves, smartly made, can set big things in motion. New York, NY: Basic Books. 
Harrison, R., Flood, D. \& Duce, D. 2013. Usability of mobile applications: Literature review and rationale for a new usability model. Journal of Interaction Science 1(1): 1-16. https://doi.org/10.1186/2194-0827-1-1

Hlavac, R. 2014. Social IMC: Social strategies with bottom-line ROI. United States: Createspace.

Hoffman, S. 2017. How to write a white paper: A closer look at white paper definition. [Online]. Available at: http://www.hoffmanmarcom.com/docs/Closer_Look_white_ paper_definition.pdf. [Accessed on 3 April 2017].

Holliman, G. \& Rowley, J. 2014. Business to business digital content marketing: Marketers' perceptions of best practice. Journal of Research in Interactive Marketing 8(4): 269293. https://doi.org/10.1108/JRIM-02-2014-0013

Hsieh, H.F. \& Shannon, S.E. 2005. Three approaches to qualitative content analysis. Qualitative Health Research 15: 1277-1288. https://doi. org/10.1177/1049732305276687

Ind, N., Iglesias, O. \& Schultz, M. 2013. Building brands together: Emergence and outcomes of co-creation. California Management Review 55(3): 5-26. https://doi.org/10.1525/ cmr.2013.55.3.5

Kaplan, A.M. 2012. If you love something, let it go mobile: Mobile marketing and mobile social media 4x4. Business Horizons 55(2): 129-139. https://doi.org/10.1016/j. bushor.2011.10.009

Kaplan, A.M. \& Haenlein, M. 2011. The early bird catches the news: Nine things you should know about micro-blogging. Business Horizons 54(2): 105-113. https://doi. org/10.1016/j.bushor.2010.09.004

Kelley, M.D. 2014. All thumbs: Mobile marketing that works. United Kingdom: Palgrave Macmillan. https://doi.org/10.1007/978-1-137-51016-7

Lai, J.Y., Debbarma, S. \& Ulhas, K.R. 2012. An empirical study of consumer switching behaviour towards mobile shopping: A push-pull-mooring model. International Journal of Mobile Communications 10(4): 386. https://doi.org/10.1504/IJMC.2012.048137

Lin, S. 2013. Research status and trend of socialized media at home and abroad. Advertising Panorama: Theory Edition 4: 7-18.

Liu, H-W. \& Huang, H-C. 2014. Tradeoff between push and pull strategy: The moderating role of brand awareness. Developments in Marketing Science: Proceedings of the Academy of Marketing Science.

Miles, M.B. \& Huberman, A.M.1994. Qualitative data analysis: An expanded sourcebook. (Second edition). Thousand Oaks: Sage.

Moulin, M. 2014. Push vs pull mobile marketing: Different tactics for different goals iZipline. [Online]. Available at: http://izipline.com/push-vs-pull-mobile-marketingdifferent-tactics-for-different-goals/ [Accessed on 6 March 2017].

Myllys, J. 2016. The role of content marketing in company branding. [Online]. Available at: http://www.doria.fi/handle/10024/119947. [Accessed on 6 March 2017]. 
Okazaki, S. 2004. How do Japanese consumers perceive wireless ads? A multivariate analysis. International Journal of Advertising 23(4): 429-454. https://doi.org/10.108 0/02650487.2004.11072894

Palka, W., Pousttchi, K. \& Wiedemann, D.G. 2009. Mobile word-of-mouth - A grounded theory of mobile viral marketing. Journal of Information Technology 24(2): 172-185. https://doi.org/10.1057/jit.2008.37

Pousttchi, K. \& Wiedemann, D.G. 2006. A contribution to theory building for mobile marketing: Categorizing mobile marketing campaigns through case study research. [Online]. Available at: http://mpra.ub.uni-muenchen.de/2925/. [Accessed on 8 March 2017].

Pulizzi, J. 2012. The rise of storytelling as the new marketing. Publishing Research Quarterly 28(2): 116-123. https://doi.org/10.1007/s12109-012-9264-5

Rubin, T. 2015. How to build a mobile community. [Online]. Available at: http://www. huffingtonpost.com/ted-rubin/how-to-build-a-mobile-community_b_7426330.html. [Accessed on 10 March 2017].

Russell, K. 2016. What are mobile marketing opt-ins and why are they important? Social media examiner. [Online]. Available at: http://www.socialmediaexaminer.com/ what-are-mobile-marketing-opt-ins-and-why-are-they-important/ [Accessed on 10 March 2017].

Sanakulov, N. \& Karjaluoto, H. 2015. Consumer adoption of mobile technologies: A literature review. International Journal of Mobile Communications 13(3): 244. https://doi. org/10.1504/IJMC.2015.069120

Santos, J.F. 2015. QR code adoption and mobile marketing practices in Portugal: An empirical study. International Journal of Marketing, Communication and New Media 3(3): 5-23.

Scharl, A., Dickinger, A. \& Murphy, J. 2005. Diffusion and success factors of mobile marketing. Electronic Commerce Research and Applications 4(2): 159-173. https:// doi.org/10.1016/j.elerap.2004.10.006

Schimke, M. 2015. 5 steps to Kickstart your mobile content marketing strategy. [Online]. Available at: http://www.adweek.com/socialtimes/5-steps-to-kickstart-your-mobilecontent-marketing-strategy/617867 [Accessed on 10 March 2017].

Schimke, M. 2016. Marketing focus 2016: The intersection of content and mobile. [Online]. Available at: http://www.websitemagazine.com/content/blogs/posts/ archive/2016/01/20/marketing-focus-2016-the-intersection-of-content-and-mobile. aspx. [Accessed on 10 March 2017].

Shankar, V. \& Balasubramanian, S. 2009. Mobile marketing: A synthesis and prognosis. Journal of Interactive Marketing 23(2): 118-129. https://doi.org/10.1016/j. intmar.2009.02.002

Shankar, V., Venkatesh, A., Hofacker, C. \& Naik, P. 2010. Mobile marketing in the retailing environment: Current insights and future research avenues. Journal of Interactive Marketing 24(2): 111-120. https://doi.org/10.1016/j.intmar.2010.02.006 
Sharif, M.S., Shao, B., Xiao, F. \& Saif, M.K. 2014. The impact of psychological factors on consumers' trust in adoption of m-commerce. International Business Research 7(5): 148-155. https://doi.org/10.5539/ibr.v7n5p148

Silver, C. \& Lewins, A. 2007. QDA Miner 3.2 (with WordStat \& Simstat). Distinguishing features and functions. Database 2. Software Reviews CAQDAS Networking Project.

Sterling, G. 2015. It's official: Google says more searches now on mobile than on desktop. [Online]. Available at: http://searchengineland.com/its-official-google-says-moresearches-now-on-mobile-than-on-desktop-220369. [Accessed on 3 March 2017].

Symons, A. 2015. The art of content: How businesses and agencies valuate digital content marketing. In: Zifei, F.C., Yi, G.J. \& Zongchao, C.L. (eds.). Proceedings of the 18th International Public Relations Research Conference, 346-374, Miami, FL: University of Miami.

Unni, R. \& Harmon, R. 2007. Perceived effectiveness of push vs. pull mobile location based advertising. Journal of Interactive Advertising 7(2): 28-40. https://doi.org/10.1080/1 5252019.2007.10722129

Vee, J., Miller, T., Bauer, J. \& Miller, J. 2008. Gravitational marketing: The science of attracting customers. United Kingdom: Wiley, John \& Sons.

Wang, K. 2015. Determinants of mobile value-added service continuance: The mediating role of service experience. Information \& Management 52(3): 261-274. https://doi. org/10.1016/j.im.2014.11.005

Welsch, E. 2002. Dealing with data: Using NVivo in the qualitative data analysis process. Forum Qualitative Social Research 33(2), May Art 26.

West, C. n.d. The importance of mobile content marketing. [Online]. Available at: http:// www.zerys.com/content-marketing-blog-1/bid/103135/The-Importance-of-MobileContent-Marketing. [Accessed on 10 March 2017]. 